Jurnal Administrasi Publik (Public Administration Journal), 10(2) December 2020

ISSN2088-527X (Print) ISSN2548-7787 (Online) DOI: https://doi.org/10.31289/iap.v10i2.3531

Jurnal Administrasi Publik (Public Administration Journal)

Available online http://ojs.uma.ac.id/index.php/jap

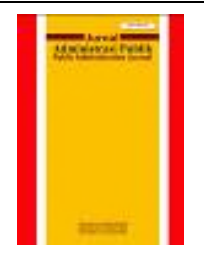

\title{
The Level of Public Awareness of the Application of the Electronic Ticket System in Surabaya
}

\author{
Ertien Rining Nawangsari *, Koko Prasetya, Muhammad Arifin, \\ Khusnul Khothimah \& Rhea Ardhana
}

Public Administration Study Program, Faculty of Social and Political Sciences, Universitas Pembangunan Nasional "Veteran" Jawa Timur, Indonesia

Received: February 23, 2020; Reviewed: May 13, 2020; Accepted: July 27, 2020

* Email Coresponding: ertien rining.adneg@upniatim.ac.id

\begin{abstract}
In Indonesia, currently there has been progress in the field of information technology. Along with the development of sophisticated and advanced technology, there are more and more demands of need. By utilizing the sophistication and advancement of existing technology, the government makes electronicbased policies, namely e-government. From the existence of this new electronic-based system, it makes easier to carry out the implementation of services carried out by the state apparatus to public. The objective of this study is to measure the level of public awareness of Surabaya people towards the application of the E-ticket system related to frequent violations. The scope of the study is the city of Surabaya. The problem is focused on the level of public awareness about the e-ticket system that has been running. In order to approach this problem, a theoretical reference from Soerjono Sukanto was used regarding public awareness. The data were collected through questionnaires spread across 31 districts in Surabaya and analyzed quantitatively with a descriptive approach. This study concludes that Surabaya people had awareness and knew a new system in ticketing, namely the electronic ticketing system, but for its application, many violations still occured. It is indicated by the percentage of $55 \%$ which is included in the fairly high category with a percentage of $70.5 \%$ regarding the existence the new system.
\end{abstract}

Keywords: Public Awareness, Electronic Government, Electronics Ticket

How to Cite: Nawangsari, ER, Prasetya, K., Arifin, M., Khothimah, K., \& Ardhana, R., (2020). The Level of Public Awareness of the Application of the Electronic Ticket System for the City of Surabaya, Jurnal Administrasi Publik (Public Administration Journal). 10(2): 156-164 


\section{INTRODUCTION}

The rapid development of science and technology makes the public sector faces bureaucratic reform in catching up with science and technology. The rapid development of information and communication technology will open up the opportunities and challenges to create, access, process and utilize information appropriately and accurately. Information is a very valuable commodity in the era of globalization to be controlled in order to improve the competitiveness of an organization, including local governments in a sustainable manner (Hasibuan, 2007). One of them was carried out by the Republic of Indonesia police in collaboration with Surabaya government, especially the Transportation Agency. Various innovations have been carried out by related parties related to public management embodied in an improvement program from a manual ticketing transformed into an electronic ticketing ticket. This case faced many challenges in the implementation process related to its mechanisms that need development and refinement. Electronic government especially E-ticket comes to address and resolve various traffic violations (Ardianto, 2007).

E-ticket is the process of getting a ticket by the police to traffic offenders, which is different from that in general, which still has to be recorded manually on a blank sheet of paper or a ticket. (Setiyanto, Gunarto, \& Wahyuningsih, SE, 2017). The E-ticket system will replace the manual ticketing system that uses a ticket form, where the violating motorist will be recorded through an application owned by police personnel. At the beginning of the emergence of E-ticket, there were pros and cons that occurred in public. The people considered E-ticket to be an inaccurate policy because it can be wrongly targeted when it came to ticketing motorized vehicle users. There were also some people who consider E-ticket to be the latest innovation from the government which is very effective. Because using the E-ticket system indicates good progress for the existing traffic control system.

Conceptually, the settlement of cases of electronic traffic violations is a court process for cases of traffic violations carried out in an integrated electronicbased manner through the support of information and technology systems, as stated in Article 1 number 2 of the Supreme Court Regulation of the Republic of Indonesia Number 12 of 2016 on how to resolve the cases traffic violations (Perdani, D., Puspita, Y., \& Hendriana, R., 2018).

The existence of e-ticket, makes the people easier to pay fines through the bank. In addition, the E-ticket fee is expected to reduce the number of violations that occur. E-ticket provides an opportunity for offenders to deposit fines directly to the bank with the facilities he has, possibly with service online, ATM, or come to the teller in person (Cermati.com, 2017).

Surabaya is one of the cities in Indonesia that has implemented the ETicket system. At the beginning of the emergence of E-Ticket, there were pros and cons that occurred in public. Many people were not aware of and know about this Eticket system. The people considered ETicket as an inaccurate policy because it could be wrongly targeted when it came to ticket motorized vehicle users. There were also some people who consider E-Ticket to be the latest innovation from the government which is very effective. Using the E-ticket system indicates good progress for the existing traffic control system. With the emergence of the E-Ticketsystem, the government hoped that people as road users will be more order and obedient when driving on the highway.

It is expected that by doing research on the level of public awareness of the application of the e-ticket system in Surabaya can be seen how much the level of public awareness about the E-ticket system which have run out. With this explanation, 
it can be seen about the urgency of implementing E-ticket system. Therefore it is important to conduct the study on the level of public awareness of the application of the E-ticket system in Surabaya.

Based on the problem, the objective of this study is to measure the level of public awareness of Surabaya towards the application of E-ticket system related to violations that often occur.

The first study was conducted by (Junef, 2014) entitled "Society Behavior Against Operation Evidence of Violation (Ticketing) in Traffic". The objectives of this study are to determine the supposed behavior of the people towards proof of violation operations (ticketing) in traffic and to find out how the people should behave towards proof of violation operations (ticketing). This study used a qualitative method by using literature study which was used to obtain related and related literature, then with a juridical descriptive approach, namely by referring to legal provisions. The results of this study indicates that there had been no change in behavior and attitudes of the people towards the proof of violation operations (ticketing). As a result, there were still many accidents, congestion and air pollution as well as traffic violations that occur as a result of people did still not obey and pay attention to the existing rules when traffic. It is necessary to have a firm legal policy on public behavior, It is as an effort to eliminate vulnerabilities, threats and disturbances to the security, the discipline and fluency traffic in order to support national development going forward.

The second study that was find out successfully was the research conducted by (Akbar \& Amalia, 2018) entitled "The Relationship between Religion and Self Awareness of the Students in Islamic Counseling Study Program Al-Azhar University Indonesia (UAI)". The objective of this study is to see the relationship between religiosity with self-awareness in UAI (counseling) study program students of
UAI. Where self-awareness is selfunderstanding intelligence in accordance with situations and conditions, which has supporting factors for strengthening selfawareness. A person's religiosity is a determining factor for how to behave, how to care and others. This research used quantitative research method. The results in this study were that the religiosity of students in this study could increase selfawareness. It was since the religious dimension increased self-awareness more sensitively, as religion which was to organize human life to be better, happier and safer in the hereafter. It can be proven by the results of the research showing that $14.5 \%$ of the result had an effect on religiosity self-awareness.

\section{RESEARCH METHOD}

The use of Information and Communication Technology (ICT) in supporting the people's needs has created various opportunities that are expected to bring innovation to improve the quality of government services, especially services for the general public, the public business, and also fellow government agencies (Mashuri Ali, 2016). E-ticket is the digitization of the ticket process, by utilizing technology it is expected that the entire ticketing process will be more efficient. In Article 272 of Law no. 22 of 2009 concerning Road Traffic and Road Transportation states that to support prosecution activities in the field of road traffic and transportation, electronic equipment can be used (Rakhmadani, 2017). In the application E-ticket system, awareness was needed to support its implementation in Surabaya.

In this study, the researchers used quantitative method. Quantitative research is research based on theory. The following are theories about public awareness of policy implementation: Awareness is a person's state of consciousness based on the attitude of knowing, understanding, feeling and remembering (Widyaningsih, 
2013).

A1. Public awareness indicators based on (Soekanto, 1982) :

\section{Knowledge \\ 2. Understanding \\ 3. Behavior \\ 4. Attitude}

A2. Policy implementation indicators based on Wisakti (2008) in Djiko \& Tapai (2014) as follows, namely standards and policy objectives, resources, communication between organizations and strengthening activities, characteristics of implementing agents, socio-political and economic conditions.

The application of the ticketing system in Surabaya was carried out by officers who did the numbering of the offending motorist by stopping the vehicle and then giving a certificate of the numbering and confiscating goods or a letter as collateral. Such a ticket system was outdated because it was considered ineffective and there were still many violations that occur.

Then ticket system update was required Surabaya (Hajeb \& Javadi, 2013). From every problem that occured, an Eticket system was created more effective so that people in traffic were more orderly. However in application of E-ticket system, the people did many commit violations eventhough they had high awareness of the implementation of the policy. Based on the above statement, then government and officers need to do more affirmation so that drivers obey the regulations. Based on the description above, the conceptual framework in public awareness in application E-ticket can be illustrated:

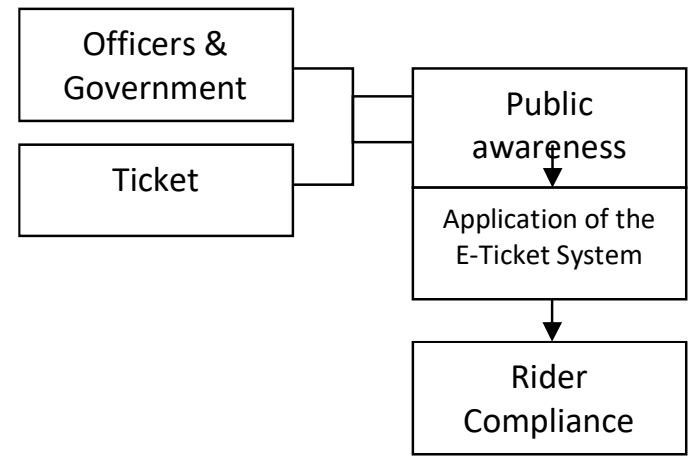

The type of research used was quantitative research with a descriptive approach. This study used a descriptive approach because it aimed to explain in detail from object research and research results. The population in this study was about the awareness of the people concerned E-ticket system. The sample in this study was Surabaya people who will be drawn randomly based on the area that consists of 31 sub-districts in Surabaya namely Tegalsari, Genteng, Bubutan, Simokerto, Gubeng, Wonokromo, Gunung Anyar, Mulyorejo, Sukolilo, Rungkut, Tenggilis, Pabean Cantian, Semampir, Krembangan, Kenjeran, Bulak, Tambaksari, Tandes, Sukomanunggal, Asemrowo, Benowo , Lakarsantri, Sambikerep, Sawahan, Pakis Hamlet, Pakal, Jambangan, Gayungan, Wonocolo, Karang Pilang, Wiyung. In this study, 200 questionnaires and documentation instruments were used by primary and secondary data sources to obtain data. The data analysis process was carried out using descriptive statistics. With descriptive statistics, researchers can briefly present data and describe the sample data.

\section{RESULTS AND DISCUSSION}

\section{Public Awareness of the Application of}

E-Ticket

Public services are all forms of public service activities carried out by government agencies at the center, in the regions, and in the environment of StateOwned Enterprises (BUMN) and RegionalOwned Enterprises (BUMD) in the form of goods and services both in an effort to meet 
the people's needs and in the framework of implementing statutory provisions (Holle, 2011). In this study, the research object used was public awareness related to ETicket, while the research subjects used were Surabaya people. The sampling technique used by researchers was a random sample based on area by distributing 200 questionnaires to be filled in by respondents in Surabaya in 31 districts, namely; Tegalsari, Genteng, Bubutan, Simokerto, Gubeng, Wonokromo, Gunung Anyar, Mulyorejo, Sukolilo, Rungkut, Tenggilis, Cantian Pabean, Semampir, Krembangan, Kenjeran, Bulak, Tambaksari, Tandes, Sukomanunggal, Asemrowo, Benowo, Lakarsantri, Sambikerep, Sawahan, Dukuh Pakis, Pakal, Jambangan, Gayungan, Wonocolo, Karang Pilang, Wiyung. Another thing that can illustrate this study is the description of research data related to research characteristics and research data through the explanation below. The collection of quantitative data in this study was carried out by distributing questionnaires using online questionnaires through the distribution of questionnaire links with Google Drive and offline questionnaires where the researchers distributed directly to respondents, namely Surabaya people spread over 31 districts. The characteristics of the respondents in this study were obtained including gender, age, and latest education level.

Tabel 1

\begin{tabular}{lll}
\multicolumn{3}{c}{ Sex of The Respondents } \\
\hline No & Sex & Total $)$ \\
\hline 1 & Male & 97 \\
2 & Female & 103 \\
Total of & Respondents & $\mathbf{2 0 0}$ \\
\hline
\end{tabular}

Judging from the questionnaire data obtained in Surabaya city, there were 97 men and 103 women. Then the rationality that was obtained in a balanced manner between each sex makes the characteristics of the study more complex with the required criteria. It was managed based on incoming data from google drive questionnaires that had been distributed to participants.

Table 2

Respondents Age Range ( $\mathrm{n}=\mathbf{2 0 0})$

\begin{tabular}{lll}
\hline No & Age Range & Total \\
\hline 1 & $17-21$ & 146 \\
2 & $22-26$ & 18 \\
3 & $27-31$ & 5 \\
4 & $32-36$ & 10 \\
5 & $37-41$ & 6 \\
6 & $42-46$ & 5 \\
7 & $47-51$ & 7 \\
8 & $52-56$ & 2 \\
9 & $57-62$ & 1 \\
\hline \multicolumn{2}{l}{ Total of Respondents } & 200 \\
\hline
\end{tabular}

From the questionnaire data obtained by the researchers in the Surabaya area, it can be seen that the people who have filled out the questionnaires were aged 17-62 years. From this table it can also be seen that on average the most interested people in filling out the questionnaire were people aged 17-36 years and the rest were people aged 37-62 years, the numbers were less because people in that age were vulnerable and less interested in filling them.

Table 3

Respondents' Last Education Level $(\mathrm{n}=\mathbf{2 0 0})$

\begin{tabular}{lll}
\hline No & Last education & Total \\
\hline $\mathbf{1}$ & No education & - \\
$\mathbf{2}$ & Elementary School & $\mathbf{2}$ \\
3 & Junior High School & 6 \\
4 & Senior High School & 178 \\
5 & Diploma & 3 \\
6 & Undergraduate students $\left(\mathrm{S}_{1}\right)$ & 10 \\
7 & Post graduate students $\left(\mathrm{S}_{2}\right)$ & $\mathbf{1}$ \\
8 & Doctor Program $\left(\mathrm{S}_{3}\right)$ & - \\
& Total of respondents & $\mathbf{2 0 0}$ \\
\hline
\end{tabular}

Source: primary data processed (questionnaire)

Judging from the data table 3 , the researcher got the questionnaire data using random sampling technique. On average, the respondents have a good final 
educational background, which is 6 years of compulsory education.

Table 4

Classification of status from the questionnaire $(\mathrm{n}=\mathbf{2 0 0})$

\begin{tabular}{|c|c|c|c|}
\hline & & $\mathrm{N}$ & $\begin{array}{l}\text { Marginal } \\
\text { Percentage }\end{array}$ \\
\hline \multirow[t]{3}{*}{ Status } & Low & 8 & $4.0 \%$ \\
\hline & Middle & 51 & $25 \cdot 5 \%$ \\
\hline & High & 141 & $70.5 \%$ \\
\hline \multirow[t]{5}{*}{ JAA } & Strongly disagree & 1 & $.5 \%$ \\
\hline & Disagree & 7 & $3 \cdot 5 \%$ \\
\hline & Quite agree & 51 & $25 \cdot 5 \%$ \\
\hline & Agree & 110 & $55.0 \%$ \\
\hline & Strongly agree & 31 & $15 \cdot 5 \%$ \\
\hline True & & 200 & $100.0 \%$ \\
\hline False & & 9 & \\
\hline Total & & 209 & \\
\hline
\end{tabular}

Judging from table 4, the classification based on the researchers is divided into 3, namely Low, Medium, and High with 4\%, $25.5 \%$, and $70.5 \%$ respectively. With a total of 209 respondents, it can be seen that the people of Surabaya agree about the applicable E-Ticket system and are aware of the E-Ticket system in Surabaya with a percentage of $55 \%$ which we can conclude that it is included in the high category with a percentage of $70.5 \%$. With the above statement the results of primary data processing from questionnaires distributed to the respondents indicates that there was no positive influence on the implemented E-Ticket system policy. In this case it has a correlation with the E-Tilcket policy in reducing the level of traffic violations, on the side of public awareness there is an inverse conjunction of the existence of the E-Ticket policy system.(Anggara, 2014). It includes elements of public awareness indicators according to (Soekanto, 1982) :

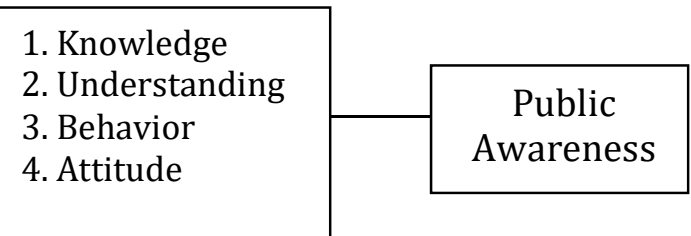

Some of the above indicators and the results of distributing questionnaires that have been distributed to 209 respondents in the city of Surabaya with five categories consisting of strongly agree, agree, quite agree, disagree and strongly disagree. It proves that most of the people of Surabaya already know and understand about the ETicket system in Surabaya. From the results of interviews conducted by researchers with the Head of the Traffic Division of Surabaya Transportation Service, Mr. Ir. Irfan Wahyudrajad, M.MT explained that:

"Up to now, after the implementation of the E-Ticket system, many people still violate traffic, even many people have protested. Regarding the awareness that you asked me, in my opinion, the public are still not aware and does not fully understand the E-Ticket system. Since there are some people who usually obey traffic regulations if there are only police, when there are no police, he still violates, but there are also people who consciously obey these rules when there are police or there are no police."

The public was aware that the ETicket system policy can provide a solution for them regarding the ticket settlement process. Judging from the behavior and attitudes of public, there were still many people who violate and did not comply with existing traffic regulations(Saputra \& Suryanef, 2019). It means that the public only knows about the policy of the E-Ticket system, but on the highway there were still many people who violated and were not afraid of the sanctions given. It can be proven by data obtained from the Surabaya Intelligence Transportation Systems (SITS): 


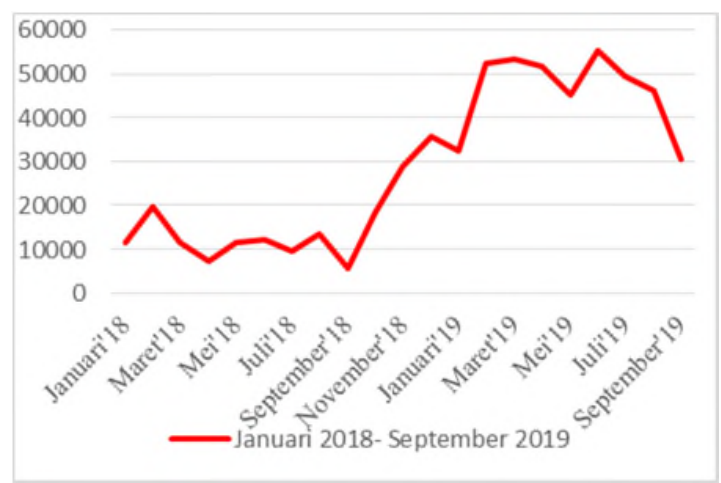

Figure 1.1

Data on Traffic Violators in Surabaya City in January 2018- September 2019

Source: Surabaya Intelligent Transport System (SITS)

With the E-ticket system, the people still committed the traffic violations, but from the data on the number of offenders from January to September 2019, the number of offenders had fluctuated and the number of offenders was uncertain. The ETicket system had been implemented at various locations in Surabaya.

\begin{tabular}{|l|}
\hline \multicolumn{1}{|c|}{ Lokasi } \\
\hline Kertajaya - Dharmawangsa Selatan \\
\hline Kertajaya - Dharmawangsa Timur \\
\hline Kertajaya - Dharmawangsa Utara \\
\hline Darmo - Al Falah Utara \\
\hline Darmo - Al Falah Selatan \\
\hline Mastrip - Wiyung \\
\hline Adityawarman - Indragiri \\
\hline Kertajaya - Manyar \\
\hline Airlangga - Dharmawangsa \\
\hline Moestopo - Dharmawangsa Timur \\
\hline Moestopo - Dharmawangsa Barat \\
\hline Gunungsari - Gajah Mada Barat \\
\hline Kutai - Hayam Wuruk Barak \\
\hline Bratang - Nginden \\
\hline Manyar - Nginden \\
\hline
\end{tabular}

Figure 2. The E-Ticket system had been implemented at various locations in Surabaya. Source: Surabaya Intelligent Transport System

\section{Level of Surabaya People Awareness as the objective of the Research}

The research discussion aims at measuring the level of awareness of the Surabaya people towards the application of the e-ticket system related to frequent violations. After doing the calculations on the questionnaire that has been filled in by the respondent. In the theory of awareness described by Soekanto (1982), these four indicators made it a benchmark for public awareness influenced by the above indicators on the policy of application the eticket system in Surabaya. The following is a description of each indicator, including:

Knowledge, it is related to public knowledge regarding the E-ticket policy in Surabaya, how the socialization of policy implementers regarding the flow of information in it.

Understanding, legal understanding of the policy of the application E-Ticket system is related to the extent to which the public know what sanctions are given when there is a violation in the policy of the ETicket system in Surabaya.

Attitudes, legal attitudes are related to how the public responds to the policy of application the e-ticket system. Where the public responded to these policies by complying with these policies or even violating these regulations.

Behavior, it is about compliance with traffic rules for public. The people as affected by the policy through the existence of E-Ticket were expected to reduce the violations that occurred in traffic rules compliance and provides a preventive effect on the people violated traffic through the E-Ticket policy.

The development of the e-government system in Indonesia in terms of quantity started to increase, but in terms of quality it was not sufficient. Efforts to improve egovernment development in Indonesia both in terms of quantity and quality requirde a commitment from the government in perfecting e-government development, especially in terms of infrastructure, human resources, applications, regulations and socialization to the public.(Sari \& Winarno, 2012). 


\section{CONCLUSION}

Surabaya people agreed the existence of a new system in ticketing, namely the ETicket system. They generally already had awareness about the new system. It can be shown by a percentage of $55 \%$ who agree with the application of the e-ticket system with a questionnaire that was distributed to respondents and was included in the high enough category with a percentage of $70.5 \%$ with public awareness who understood the existence of this e-ticket system. Although Surabaya people agreed and were aware of the E-Ticket system, its implementation was still lacking. Observed from the field, there were still many road users who violated traffic such as violating road markings, violating signs, breaking traffic lights, and so on can be proved by the above graphic of violation the ticket which still increase and decrease.

\section{BIBLIOGRAPHY}

Akbar, M. Y. A., \& Amalia, R. M. (2018). Hubungan Relijiusitas dengan Self Awareness Mahasiswa Program Studi Bimbingan Penyuluhan Islam (Konseling) Universitas AlAzhar Indonesia. Jurnal Al-Azhar Indonesia Seri Humaniora, 4(4), 265. https://doi.org/10.36722/sh.v4i4.304

Anggara, S. (2014). Kebijakan Publik (1st ed.; T. R. P. Setia, ed.). Bandung: Pustaka Setia.

Ardianto, N. (2007). Good E-Goverment: Transparansi dan Akuntabilitas Publik Melalui E-Goverment (1st ed.). Malang: Bayumedia.

Cermati.com. (2017). Mengenal E-Tilang Layanan Tilang Berbasis Online dari Kepolisan.

Djiko, R., \& Tangkau, C. H. S. (2014). Implementasi Kebijakan Jaminan Kesehatan Nasional di Kabupaten Halmahera Utara. Administrasi Publik, 1(1), 127-136.

Hajeb, S., \& Javadi, M. (2013). Traffic Violation Detection System Based on RFID. Mechanical and Mechatronics Engineering, 7(2), 290-293.

Hasibuan, Z. A. (2007). Langkah-Langkah Strategis dan Taktis Pengembangan E-Government untuk Pemda. Jurnal Sistem Informasi MTI UI Vol 3, 3(1), 1-5.

Holle, E. S. (2011). Pelayanan Publik Melalui Electronic Government : Upaya Meminimalisir Praktek Maladministrasi Dalam Meningkatkan Public Service. Jurnal Sasi, 17(3), 21-30.

Junef, M. (2014). Perilaku Masyarakat Terhadap Operasi Bukti Pelanggaran (Tilang) Dalam Berlalu Lintas. E-Journal WIDYA Yustisia, 1(1), 52-60.

Mashuri Ali, M. (2016). Analisis Transparansi Layanan Pengadaan Barang Dan Jasa Secara Elektronik (Lpse) Pada Kantor Komunikasi Dan Informasi Kabupaten Maros Provinsi Sulawesi Selatan. Jurnal Dinamika Governance, 1(1), 13-22. Retrieved from http://ejournal.upnjatim.ac.id/index.php/jd g/article/view/1198

Perdani, D., Puspita, Y., \& Hendriana, R. (2018). Penerapan E-Tilang Bebasis CCTV ( Closed Circuit Television ) Di Kabupaten Banyumas. Penerapan E-Tilang Bebasis CCTV (Closed Circuit Television ) Di Kabupaten Banyumas, (November), 93-102. Purwokerto.

Rakhmadani, S. (2017). Analisis Penerapan E-Tilang Dalam Mewujudkan Good Governance Di Indonesia. Prosiding SNaPP2017 Sosial, Ekonomi, Dan Humaniora, 7(3), 663-671.

Saputra, B., \& Suryanef, A. (2019). Dalam Implementasi Rencana Tata Ruang Wilayah ( Rt/Rw ) Kota Padang. Pembangunan Nagari, 4(1), 71-82.

Sari, K. D. A., \& Winarno, W. A. (2012). Implementasi E-Goverment System Dalam Upaya Peningkatan Clean And Good Goverment Di Indonesia. JEAM, 11(1), 1-19.

Setiyanto, Gunarto, \& Endah Wahyuningsih, S. (2017). Efektivitas Penerapan Sanksi Denda E-Tilang Bagi Pelanggar Lalu Lintas Berdasarkan Undang-Undang Nomor 22 Tahun 2009 Tentang Lalu Lintas Dan Angkutan Jalan (Studi Di Polres Rembang). Jurnal Hukum Khaira Ummah, 12(4), 754766.

Soekanto, S. (1982). Kesadaran Hukum dan Kepatuhan Hukum (1st ed.). Jakarta: Rajawali.

Widyaningsih, N. D. (2013). Hubungan Antara Tingkat Pendidikan Masyarakat Dengan Kesadaran Masyarakat Dalam Pembangunan Desa. Educitizen, 1(1), 68-77. 